\title{
POLITIK DAN EKONOMI TERENGGANU PADA HUJUNG ABAD KE-18: KAJIAN TERHADAP WARKAH SULTAN MANSUR SHAH I
}

\section{(The Politics and Economy of Terengganu in the Late 18th Century: A Study of the Letters of Sultan Mansur Shah I)}

\author{
Abd ur-Rahman Mohamed Amin \\ urrahman_amin@utp.edu.my \\ Jabatan Pengurusan dan Kemanusiaan, \\ Fakulti Sains dan Teknologi Maklumat, \\ Universiti Teknologi PETRONAS
}

Terbit dalam talian (published online): 7 Julai 2020

Sila rujuk: Abd ur-Rahman Mohamed Amin. (2020). Politik dan Ekonomi Terengganu pada Hujung Abad Ke-18: Kajian terhadap Warkah Sultan Mansur Shah I. Melayu: Jurnal Antarabangsa Dunia Melayu, 13(2), 271-298.

\begin{abstract}
Abstrak
Artikel ini membincangkan tentang kandungan 17 pucuk warkah kiriman Sultan Terengganu, iaitu Sultan Mansur Shah I kepada Francis Light yang tersimpan di perpustakaan School of Oriental and African Studies, University of London dengan nombor rujukan SOAS MS 40320. Warkah bertulisan jawi ini telah dikirim sekitar tahun 1785 hingga tahun 1794. Kandungannya merangkumi politik Terengganu yang melibatkan hubungan luar dengan Siam dan Inggeris. Siam sentiasa mengugut untuk menyerang Terengganu terutamanya selepas Siam menawan Patani pada tahun 1785. Terengganu berusaha menjalinkan hubungan diplomatik dengan kompeni Inggeris untuk melindunginya daripada serangan Siam. Namun begitu, usaha tersebut tidak berjaya disebabkan dasar tidak campur tangan kompeni Inggeris. Dalam aspek ekonomi, Terengganu menjalin hubungan dagang dengan Palembang yang membekalkan lada dan timah dan pelabuhan di Jawa dan Borneo. Terengganu turut mempunyai hubungan perdagangan antarabangsa dengan China dan India. Perdagangan Sultan Terengganu diuruskan oleh saudagar raja, iaitu Saudagar Nasruddin. Kapal-kapal Inggeris turut digunakan untuk menumpangkan bakal haji ke
\end{abstract}

(C) Dewan Bahasa dan Pustaka. 2020. This work is licensed under the term of the Creative Commons Attribution (CC BY) (http://creative commons.org/licenses/by/4.0/)

ISSN 1675-6460 e-ISSN 2682-8049 
Mekah melalui pelabuhan di Pulau Pinang dan India. Warkah ini turut menceritakan jalur keturunan Sultan Mansur Shah I yang berkait rapat dengan kesultanan Johor dan Patani. Keseluruhan kandungan warkah ini membantu memberikan maklumat yang lebih terperinci terhadap politik dan ekonomi kesultanan Terengganu pada hujung abad ke-18.

Kata kunci: Koleksi Surat-surat Francis Light, Terengganu, Sultan Mansur Shah I, cap mohor

\begin{abstract}
This article discusses the contents of 17 letters from Sultan Mansur Shah I, the Sultan of Terengganu, are preserved in the library of the School of Oriental and African Studies at the University of London with the reference number SOAS MS 40320. Written in Malay using Arabic script, these were sent between 1785 and 1794. The contents discuss the political history of Terengganu involving foreign relations with the Siamese and the British. The Siamese were a continuous threat to Terengganu, especially after the Siamese conquest of Patani in 1785. Therefore, Terengganu sought to establish diplomatic relations with the British East India Company to protect it from the Siamese invasion. However, the attempt was unsuccessful due to the East India Company's principle of non-involvement in Malay affairs. In terms of economy, Terengganu had trade links with Palembang, which supplied pepper and tin, as well as with ports in Java and Borneo. Terengganu also had trade relations with China and India. The Sultan of Terengganu employed a royal merchant, Saudagar Nasruddin, to manage his trade. British ships were used to carry pilgrims to Mecca through ports in Pulau Pinang and India. The letters also discuss the lineage of Sultan Mansur Shah I, which closely links him to the Johor and Patani sultanates. The entire contents of these letters have helped to provide more detailed information on the politics and economy of the Terengganu sultanate in the late 18th century.
\end{abstract}

Keywords: The Light Letters, Terengganu, Sultan Mansur Shah I, Malay seals

\title{
PENDAHULUAN
}

Negeri Terengganu yang terletak di Pantai Timur Semenanjung Tanah Melayu memiliki sejarah pemerintahan yang panjang. Penemuan Batu Bersurat Terengganu menandakan kewujudan sebuah pemerintahan beraja di Terengganu yang mewartakan hukuman jenayah Islam dalam undang-undangnya. Terdapat dua pendapat yang kuat 
berkaitan dengan tarikh yang tercatat pada Batu Bersurat ini, iaitu pada 4 Rejab 702 Hijrah bersamaan 22 Februari 1303 (al-Attas, 1970) ataupun 6 Rejab 708 Hijrah bersamaan 20 Disember 1308 (Ahmat, 2017). Meskipun terdapat perbezaan dari segi bacaan tarikhnya, namun kedua-dua tarikh tersebut memberikan gambaran bahawa batu bersurat telah ditulis pada awal abad ke-14.

Selain Batu Bersurat Terengganu, terdapat juga sumber manuskrip tempatan yang menceritakan kewujudan pemerintahan beraja di Terengganu. Contohnya, dalam manuskrip Sulalatus Salatin, terdapat penceritaan tentang pemerintahan Terengganu yang telah diserahkan kepada Seri Akar Raja oleh Sultan Muhammad Syah dari Pahang setelah kematian Telanai Terengganu (A. Samad, 1979). Istilah "Telanai" kemungkinan merujuk gelaran ketua Orang Laut di Terengganu (Andaya, L., 2012). Manuskrip Hikayat Hang Tuah pula telah mencatatkan ketibaan kapal Mendam Berahi di Terengganu membawa rombongan untuk bertemu dengan Sultan Terengganu (Kassim, 1975). Selain itu, dalam manuskrip Tuhfat al-Nafis, terdapat catatan berkaitan dengan hubungan politik antara kesultanan Terengganu dengan pemerintahan di Pahang, Kelantan, Johor dan Riau (Raja Ali Haji, 1998).

Sejak kurun ke-18, beberapa catatan berkaitan dengan pemerintahan beraja di Terengganu turut ditemui daripada sumber Eropah. Antaranya termasuklah catatan Alexander Hamilton ketika beliau singgah di Terengganu pada tahun 1719 dalam pelayarannya ke Siam. Beliau menyatakan bahawa Terengganu diperintah oleh seorang Raja, dan mempunyai pelabuhan untuk kapal-kapal berlabuh dan berlindung daripada badai angin dan ombak yang kuat (Hamilton, 2013). Pada 14 Jun 1764, pedagang Inggeris, iaitu Joseph Jackson pernah berjanji kepada sultan Terengganu untuk mewujudkan penempatan Inggeris di Terengganu (Khoo, 1984; McNab, 1914).

Selain pelayar Inggeris, terdapat catatan sekumpulan pelayar Perancis yang pernah tiba di Terengganu pada hujung bulan Julai 1769 ketika dalam pelayaran ke Luzon dan New Zealand. Menurut Pottierdel' Horme, ketika tiba di Terengganu, beliau tidak dapat mengadap Sultan Mansur Shah I di istana kerana dimaklumkan bahawa baginda sudah lima bulan tidak berada di istananya dan pemerintahan pada masa itu dijalankan oleh bapa saudara baginda (Dunmore, 1973).

Sumber penulisan berkaitan dengan kesultanan Terengganu semakin banyak ditemui pada kurun ke-19. Koleksi warkah Sultan Baginda Omar menjadi sumber rujukan penting kepada sejarah pemerintahan baginda (Raimy, 2015). Munsyi Abdullah turut mencatatkan beberapa perkara berkaitan dengan kesultanan Terengganu ketika singgah di sana dalam pelayarannya dari Singapura ke Kelantan pada April 1838 (Skinner, 1966). Beliau menyatakan bahawa pada ketika itu, Sultan Terengganu, iaitu Sultan Mansur Shah II telah mangkat dan digantikan oleh anaknya 
yang bernama Sultan Muhammad yang hanya berumur sekitar 15 ataupun 16 tahun (Sweeney, 2005).

Kesan daripada penjajahan Inggeris di Pulau Pinang, Melaka dan Singapura, semakin banyak catatan daripada sumber Inggeris boleh ditemui berkaitan dengan kesultanan Terengganu pada kurun ke-19. Antaranya termasuklah catatan Medhurst yang tiba di Terengganu pada tahun 1828 dan Earl pada tahun 1833 (Khoo, 1984), Clifford yang berada di Terengganu pada 1895 (Clifford, 1938) dan laporan ekspedisi dari Universiti Cambridge oleh Skeat pada tahun 1899 (Gibson-Hill, Skeat \& Laidlaw, 1953).

Berdasarkan sumber bertulis di atas, sumber bertulis daripada istana Terengganu agak sukar ditemui, melainkan warkah Sultan Baginda Omar (Abdullah Zakaria, 2006; Raimy, 2012), warkah Sultan Zainal Abidin III, warkah Sultan Sulaiman Badrul Alam Shah (Narizan, 2006), manuskrip Dato Mata-mata Nara Wangsa Mohamed Ali (Marriott, 1916), manuskrip Salasilah Kesultanan Terengganu (Arba'iyah, 2006) dan beberapa manuskrip berkaitan dengan Sultan Zainal Abidin III (Jelani, 2017). Kepentingan sumber istana sebagai sumber utama dalam kajian terhadap kesultanan Terengganu amat diperlukan bagi mengimbangi perspektif yang datang daripada sumber Eropah.

Oleh itu, penemuan warkah Sultan Mansur Shah I dalam Koleksi Warkah Francis Light merupakan penemuan yang penting untuk memberikan maklumat yang lebih mendalam tentang pemerintahan baginda. Warkah bertulisan Jawi dari kurun ke-18 ini masih tersimpan dengan baik di bahagian Arkib dan Koleksi Khas, Perpustakaan School of Oriental and African Studies, University of London dengan nombor rujukan MS 40320. Kajian ini telah dijalankan terhadap warkah kiriman Sultan Mansur Shah I dengan tumpuan diberikan terhadap kandungannya yang melibatkan aspek politik dan ekonomi. Kandungan warkah ini menerangkan dengan lebih terperinci berkaitan dengan dasar luar pemerintahan Sultan Mansur Shah I pada akhir abad ke-18 yang melibatkan Siam dan Inggeris. Warkah ini juga membantu menjelaskan lagi aspek ekonomi Terengganu yang berkaitan dengan komoditi, jaringan perdagangan dan peraturan perdagangan yang mesti dipatuhi.

\section{LATAR BELAKANG SULTAN MANSUR SHAH I}

Latar belakang Sultan Mansur Shah I tidak dapat dipisahkan dengan kesultanan Johor. Ayahanda baginda, iaitu Sultan Zainal Abidin Shah I merupakan anakanda kepada Bendahara Johor, iaitu Tun Habib Abdul Majid. Sebelum baginda ditabalkan menjadi Sultan Terengganu, namanya ialah Tun Zainal Abidin bin Tun Habib Abdul 
Majid. Tun Habib Abdul Majid merupakan Bendahara kesultanan Johor yang digelar Bendahara Padang Saujana dan pernah berkhidmat di bawah pemerintahan Sultan Ibrahim dan Sultan Mahmud Shah (Raja Ali Haji, 1984). Selepas kematian Tun Habib Abdul Majid pada tahun 1697, tempat beliau sebagai Bendahara Johor telah digantikan oleh anakandanya yang pertama, iaitu Tun Abdul Jalil yang juga merupakan kekanda kepada Tun Zainal Abidin.

Selepas kemangkatan Sultan Johor, iaitu Sultan Mahmud Shah akibat dibunuh oleh Megat Seri Rama di Kota Tinggi pada tahun 1699, kesultanan Johor menghadapi kebuntuan untuk mencari pengganti kerana ketiadaan pewaris takhta daripada keturunannya. Oleh itu, Kesultanan Johor telah diteruskan dengan pelantikan daripada keluarga Bendahara Johor, iaitu Tun Abdul Jalil (Raja Ali Haji, 1984). Tun Abdul Jalil telah menaiki takhta kesultanan Johor dengan gelaran Sultan Abdul Jalil Riayat Shah. Bukan sekadar institusi kesultanan, institusi Bendahara dan Temenggung Johor turut dilantik daripada jurai keturunan Sultan Abdul Jalil Riayat Shah (Trocki, 2013). Selepas dilantik sebagai Sultan Johor, kesemua anak baginda yang lahir selepas itu telah mendapat gelaran sebagai Tengku dan Raja (Abdullah Zakaria, 1997).

Sultan Abdul Jalil Riayat Shah telah mengurniakan seluruh jajahan negeri Terengganu kepada adindanya, iaitu Tun Zainal Abidin untuk diperintah dan seterusnya ditabalkan sebagai Sultan Zainal Abidin Shah. Pengurniaan tersebut telah disahkan oleh sultan Johor kemudiannya, iaitu Sultan Sulaiman Badrul Alam Shahibni al-Marhum Sultan Abdul Jalil Riayat Shah pada zaman pemerintahan Sultan Mansur Shah I. Peristiwa pemasyhuran ini berlaku pada tahun 1740 ketika Sultan Sulaiman Badrul Alam Shah berada di Terengganu (Sheppard, 1949). Sultan Mansur Shah I menegaskan:

... adapun akan hal Sultan Abdul Jalil itu memberikan negeri Terengganu itu kepada saudaranya Sultan Zainal Abidin dan kemudian pula pada masa Sultan Sulaiman jadi raja di negeri Riau maka negeri Terengganu itupun diberikan Sultan Sulaiman pula akan Sultan Mansur mengesahkan pemberian Sultan Abdul Jalil akan Sultan Zainal Abidin ...

(MS 40320/11, f.69)

Sultan Mansur Shah I telah dilahirkan sekitar tahun 1726. Ayahanda baginda, iaitu Sultan Zainal Abidin mangkat pada 7 Mac 1733 (Andaya, B.W., 1976). Umur baginda hanyalah sekitar tujuh tahun pada masa itu. Kesemua kekanda baginda telah menolak untuk menggantikan tempat Sultan Zainal Abidin yang telah mangkat dan 
memberikan hak mereka kepada adinda mereka, iaitu Sultan Mansur Shah I. Oleh sebab baginda masih terlalu muda, baginda hanya ditabalkan sebagai sultan pada 26 Februari 1741 (Andaya, B.W., 1976). Sebelum pertabalannya, pemerintahan baginda dipangku oleh Tun Husain Bendahara (Sheppard, 1949). Sultan Mansur Shah I juga dikenali dengan gelaran Ku Tana Mansur, Tun Dalam, Raja Kecil, Yang Dipertuan Kecil dan Marhum Janggut (Abdullah Zakaria, 2012).

Sultan Mansur Shah I sendiri mengakui bahawa keturunannya mempunyai kaitan dengan Kesultanan Johor dan Riau. Baginda menyatakan:

... asal Raja Johor itu banyak adik-beradiknya dan yang jadi raja dua beradik dan yang jadi Raja Johor itu Sultan Abdul Jalil namanya ia beranakkan Sultan Sulaiman dan Sultan Sulaiman itu beranakkan Raja Muda dan Raja Muda itu beranakkan Sultan Mahmud yang jadi Raja Riau sekarang ini ...

(MS 40320/11, f.69)

Baginda juga mengakui bahawa bondanya merupakan seorang wanita yang memiliki darah kesultanan Patani. Bonda baginda ialah anakanda kepada Dato Muda yang merupakan saudara kepada Long Bahar, iaitu Raja Patani. Baginda menyatakan:

... Sultan Zainal Abidin itu pergi beristeri ke Patani akan anak Dato' Muda saudara kepada Raja Patani, iaitu Long Bahar maka lalu beranakkan Sultan Mansur yang jadi Raja Terengganu ...

(MS 40320/11, f.69)

Perkahwinan Sultan Zainal Abidin dengan wanita daripada kesultanan Patani tidak menghairankan kerana Sultan Zainal Abidin pernah tinggal di Patani dan diangkat sebagai anak oleh Raja Patani (Mohamed Anwar et al., 2011). Nama wanita kesultanan Patani yang dikahwini oleh Sultan Zainal Abidin ialah Nang Rugayah (Misbaha, 1992). Berdasarkan jurai keturunan Sultan Mansur Shah I, ternyata bahawa baginda sememangnya mempunyai hubungan darah dengan kesultanan Johor daripada sebelah ayahanda dan kesultanan Patani daripada sebelah bonda.

Apabila dewasa, Sultan Mansur Shah I telah berkahwin dengan anakanda Sultan Johor, iaitu Sultan Sulaiman Badrul Alam Shah yang bernama Raja Bakul (Sheppard, 1949). Baginda turut berkahwin lagi dengan beberapa orang wanita, antaranya ialah puteri Yam Tuan Muda Daeng Celak (Misbaha, 1992). Sultan Sulaiman Badrul Alam Shah yang memerintah Johor dan mangkat pada tahun 1760 merupakan sepupu dan bapa mentua kepada Sultan Mansur Shah I. Perkahwinan Sultan Mansur Shah 
I dinyatakan sendiri oleh baginda seperti berikut: “... maka Sultan Mansur pun beristerikan anak Sultan Sulaiman ...” (MS 40320/11, f.69).

Sultan Mansur Shah I telah mangkat pada malam Jumaat, 14 Jamadil Akhir 1208 bersamaan dengan 17 Januari 1794 dan dimakamkan keesokan harinya selepas waktu asar di kawasan Masjid Abidin, Kuala Terengganu (Marriott, 1916). Usia baginda pada masa itu sekitar 68 tahun. Tarikh kemangkatan baginda telah dimaklumkan oleh anakanda baginda, iaitu Sultan Zainal Abidin II dalam warkahnya kepada Francis Light (MS 40320/11, f.102).

\section{WARKAH SULTAN MANSUR SHAH I}

Warkah Sultan Mansur Shah I dalam Koleksi Francis Light ini belum pernah dikaji secara menyeluruh. Kajian awal berkaitan dengan warkah ini telah dilakukan oleh Marsden (1812) yang telah menterjemahkan enam pucuk warkah Sultan Mansur Shah I kepada Bahasa Inggeris. Marsden (1812) menjadikan warkah ini sebagai panduan penggunaan bahasa Melayu dalam bidang persuratan. Imej sepucuk warkah Sultan Mansur Shah I, iaitu MS 40320/11, f.80, turut dipilih untuk diterbitkan dalam penerbitan berkaitan dengan warkah-warkah Melayu oleh Gallop (1994).

Dalam Koleksi Warkah Francis Light, sebahagian besar warkah yang dikirim dari Terengganu adalah daripada Sultan Mansur Shah I, Sultan Zainal Abidin Shah II

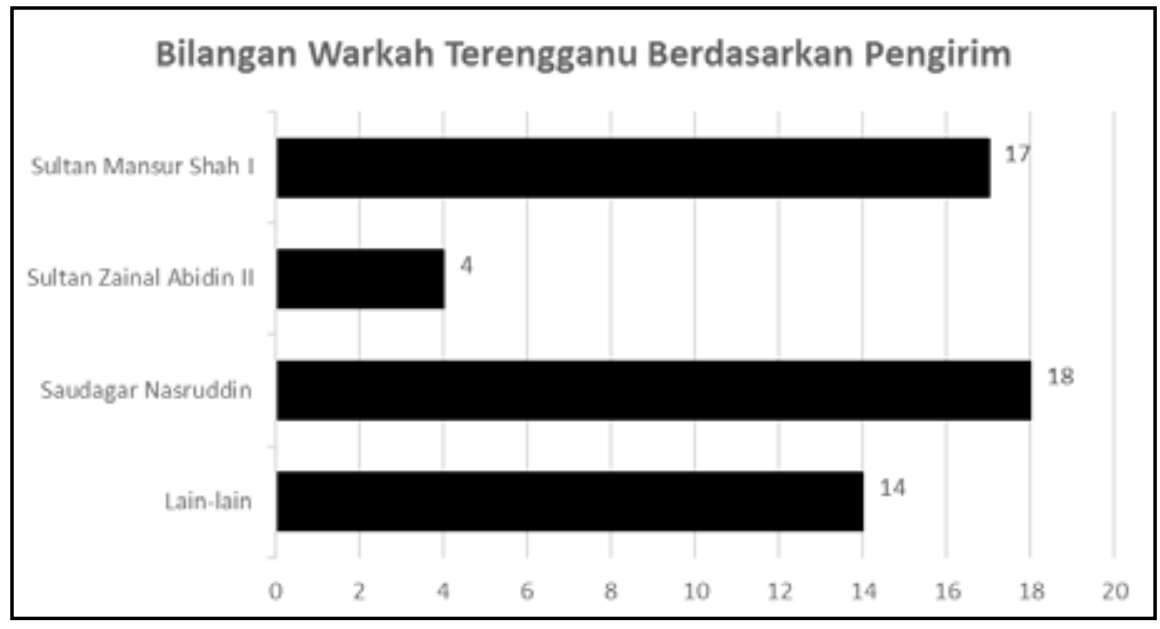

Rajah 1 Graf bilangan warkah Terengganu berdasarkan pengirim. (Sumber: MS 40320, SOAS, Universityof London) 
dan Saudagar Nasruddin. Terdapat juga warkah yang dikirim oleh individu yang lain. Rajah 1, iaitu graf yang menunjukkan bilangan warkah dari Terengganu berdasarkan pengirim.

Berdasarkan Rajah 1, bilangan warkah yang dikirim oleh Saudagar Nasruddin adalah yang tertinggi, iaitu sebanyak 18 pucuk warkah diikuti oleh warkah kiriman Sultan Mansur Shah I sebanyak 17 pucuk warkah dan Sultan Zainal Abidin Shah II sebanyak empat pucuk warkah sahaja. Warkah yang dikirim daripada sumber yang lain merupakan sejumlah warkah yang dikirim oleh individu seperti warkah kiriman Francis Light (enam pucuk), Sayid Muhamad (empat pucuk), Sayid Othman, Sayid Alawi, Farley dan adinda Nian. Jumlah warkah dari Terengganu yang ditemui dalam koleksi Warkah Francis Light adalah sebanyak 53 pucuk warkah.

Warkah yang dikirim oleh Sultan Mansur Shah I dapat dikenali berdasarkan cap mohor baginda yang terdapat dalam warkah tersebut. Terdapat sepucuk warkah yang tidak mempunyai cap baginda. Kesemua warkah baginda menggunakan cap mohor yang sama. Baginda sebenarnya memiliki satu lagi cap mohor yang berbeza daripada yang digunakan dalam koleksi ini. Cap mohor itu lebih ringkas kerana tidak diukir dengan nama ayahanda baginda seperti yang dapat dilihat dalam karya berkaitan dengan cap mohor di alam Melayu oleh Gallop (2019).

Berdasarkan Rajah 2, cap mohor baginda yang digunakan dalam koleksi ini berbentuk bulatan dan mengandungi lima baris perkataan yang tertulis "al-Sultan Mansur Ri'ayat Shah Zillullah fi al-'Alam ibnal-Sultan Zainal 'Abidin”. Dalam cap

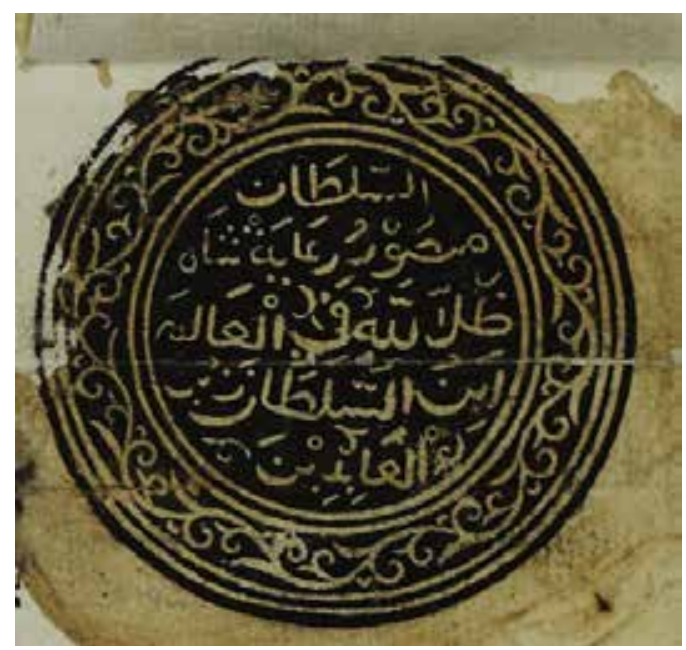

Rajah 2 Cap mohor Sultan Mansur Shah 1. 


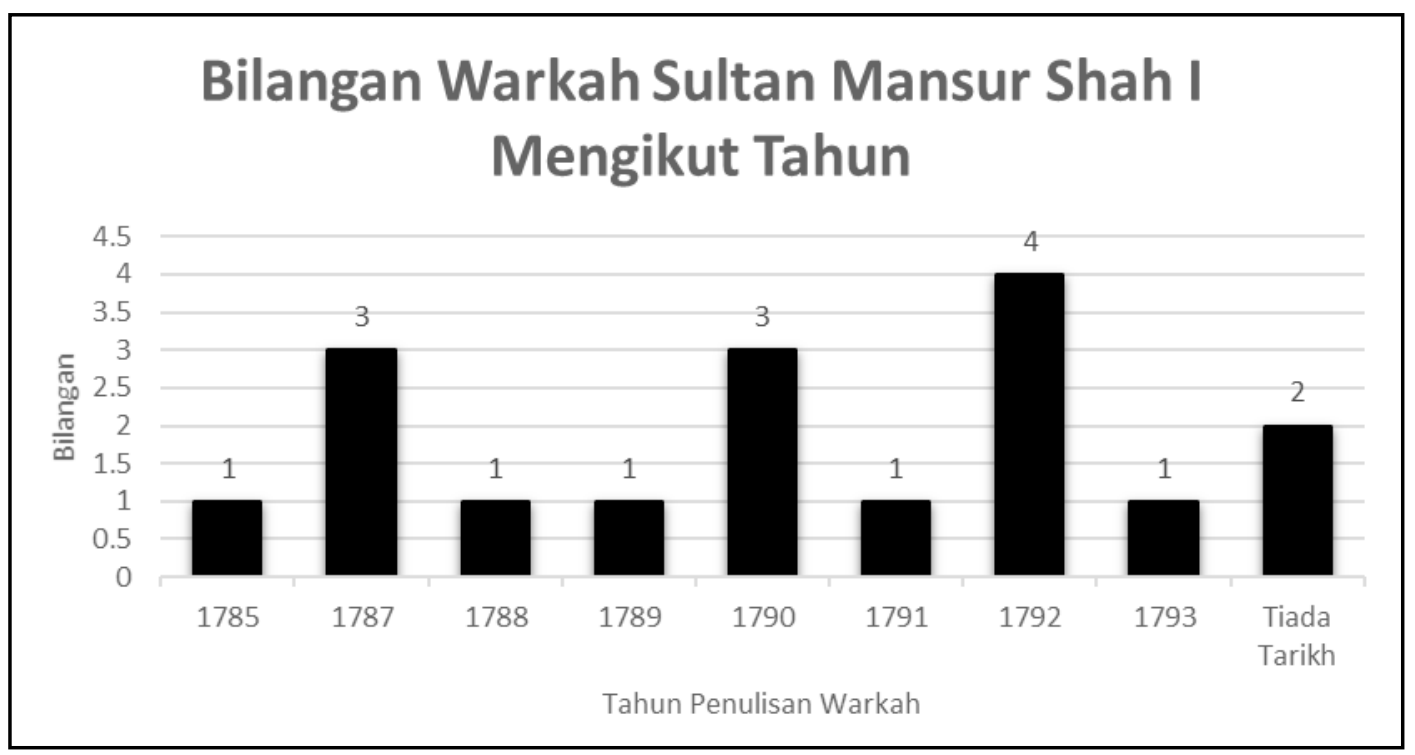

Rajah 3 Graf bilangan warkah Sultan Mansur Shah I mengikut tahun.

(Sumber: MS 40320, SOAS, Universityof London)

mohor ini tertulis nama penuh baginda, iaitu Sultan Mansur Ri'ayat Shah ibn Sultan Zainal Abidin. Cap mohor ini tidak mencatatkan sebarang tahun. Terdapat ukiran corak di sekeliling cap mohor baginda.

Rajah 3 di atas menunjukkan bilangan warkah yang dikirim oleh baginda kepada Francis Light berdasarkan tahun. Warkah terawal yang dikirimkan kepada Francis Light yang ditemui dalam koleksi ini bermula pada tahun 1785 dan berakhir pada tahun 1793. Baginda mangkat pada 17 Januari 1794. Hampir setiap tahun baginda mengirimkan warkah kepada Francis Light melainkan pada tahun 1786. Warkah yang paling banyak dikirimkan adalah pada tahun 1792, iaitu sebanyak empat pucuk warkah dan diikuti oleh tahun 1787 dan 1790 dengan tiga pucuk warkah. Terdapat dua pucuk warkah yang tidak dicatatkan tarikh kiriman. Kewujudan warkah baginda kepada Francis Light bermula pada tahun 1785, iaitu ketika Francis Light sudah pun berada di Pulau Pinang. Penggunaan tarikh dalam semua warkah baginda menggunakan sistem tahun hijrah tanpa sebarang penggunaan tahun Masihi ataupun tahun windu. Dalam tradisi penulisan warkah Melayu, tahun windu kebiasaannya ditulis bersama-sama dengan tahun hijrah. Tahun windu merujuk pusingan lapan tahun yang ditulis berdasarkan kiraan tahun hijrah, iaitu tahun alif, tahun ha, tahun jim, tahun zai, tahun dal awal, tahun ba, tahun wau dan tahun dal akhir (Ahmat, 2009). 
MELAYU: JURNAL ANTARABANGSA DUNIA MELAYU JILID 13 BIL. 2 JULAI 2020

Jadual 1 Kepala surat warkah Sultan Mansur Shah I.

\begin{tabular}{|l|c|}
\hline Kepala Surat & Bilangan \\
\hline al-Shams wa al-Qamar & 5 \\
\hline Qawluhu al-Haqq & 4 \\
\hline al-Shams wa al-Qamar wa al-Nujum & 3 \\
\hline Qawluhual-Haqq wa Kalamuhual-Sidq & 2 \\
\hline Nur al-Shams wa al-Qamar & 1 \\
\hline Bismillah al-Rahman al-Rahim & 1 \\
\hline Qultu & 1 \\
\hline
\end{tabular}

Kepala surat yang ditulis di bahagian atas warkah memainkan peranan yang penting untuk menunjukkan kedudukan pengirim dan penerima warkah. Penggunaan kepala surat dalam warkah baginda kepada Francis Light boleh diperhatikan dalam Jadual 1.

Jadual 1 menunjukkan dengan jelas bahawa terdapat pelbagai jenis kepala surat yang telah digunakan dalam warkah baginda kepada Francis Light. Frasa "al-Shams wa al-Qamar" yang bermaksud "matahari dan bulan" mendapat kekerapan yang tinggi dengan lima pucuk warkah diikuti dengan frasa "Qawluhu al-Haqq" yang bermaksud "Kata-katanya yang benar" dengan empat pucuk warkah. Meskipun kesemua 17 pucuk warkah dikirimkan kepada Francis Light, namun terdapat sebanyak tujuh bentuk penggunaan kepala surat yang berlainan.

Rajah 4 menunjukkan bilangan perkataan yang terdapat dalam setiap warkah Sultan Mansur Shah I. Terdapat sepucuk warkah yang ditulis dengan begitu panjang sehingga menjangkau 1576 patah perkataan. Empat pucuk warkah telah ditulis dengan bilangan perkataan yang melebihi 1000 patah perkataan. Warkah yang paling pendek pula ditulis dalam lingkungan 173 patah perkataan dan merupakan surat cit, berbeza dengan warkah yang lain. Sebanyak tujuh pucuk warkah yang ditulis kurang daripada 500 patah perkataan. Secara kebiasaannya, warkah baginda ditulis dengan kandungan yang agak panjang kepada Francis Light, iaitu melebihi 600 patah perkataan.

Pada mukadimah warkah, baginda memperkenalkan dirinya sebagai "Paduka Seri Ayahanda" ataupun "Paduka Seri Sultan" ataupun "Yang Dipertuan Besar" negeri Terengganu. Kesemua gelaran tersebut menggambarkan kedudukan baginda sebagai sultan berdaulat yang memerintah sebuah negeri, iaitu Terengganu. Negeri 


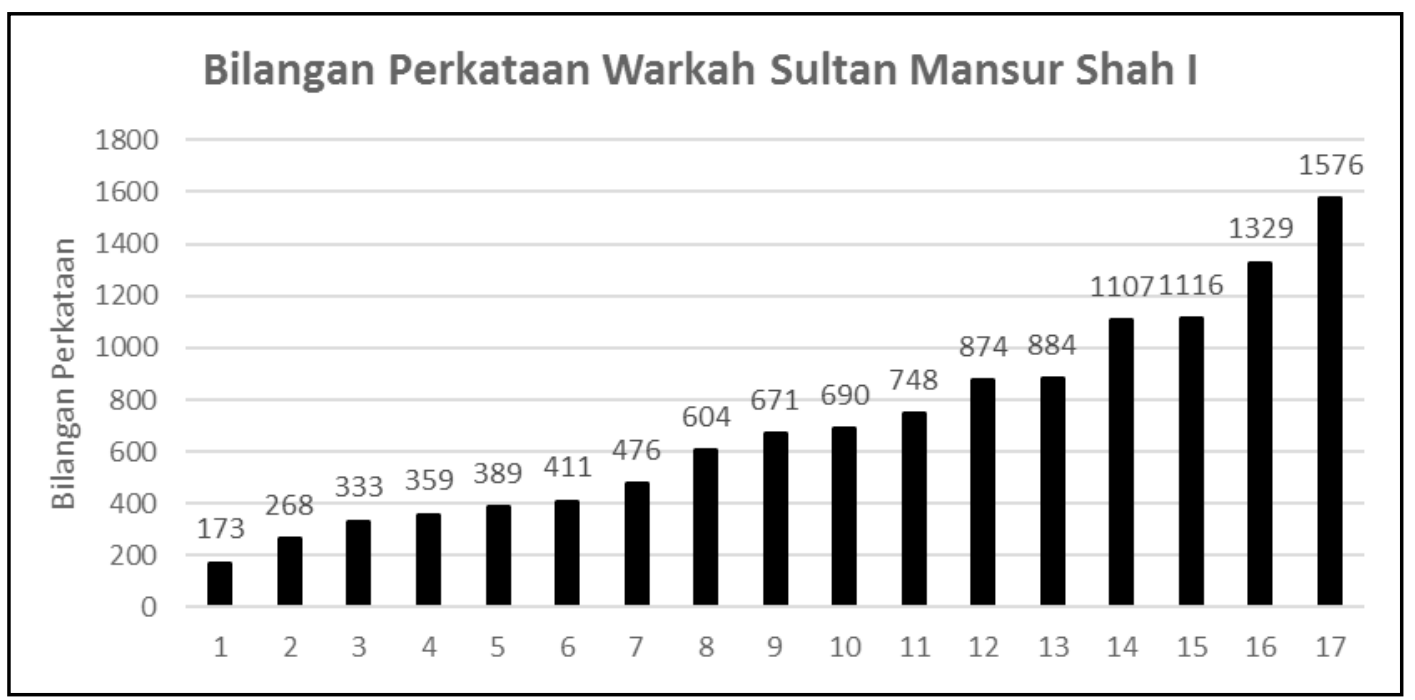

Rajah 4 Graf anggaran bilangan perkataan dalam warkah Sultan Mansur Shah I. (Sumber: MS 40320, SOAS, Universityof London)

Terengganu diistilahkan sebagai "Darul Salam". Francis Light pula diberikan pujipujian sebagai "kekasih kita", "sahabat kita" dan "anak kita".

Pada kandungan warkah pula, baginda membahasakan diri baginda sebagai "Seri Paduka ayahanda" dan "kita" sementara baginda membahasakan Francis Light sebagai "sahabat kita" dan "anak kita". Penggunaan "ayahanda" dan "anak kita" menunjukkan bahawa umur baginda jauh lebih tua daripada Francis Light. Dalam bahagian penutup, kesemua warkah baginda telah diletakkan tarikh hijrah melainkan dua pucuk surat sahaja yang tidak dicatatkan tarikh penulisan warkah.

\section{Aspek Politik}

Sistem pemerintahan yang digunakan pada zaman Sultan Mansur Shah I mempunyai banyak persamaan dengan struktur pemerintahan yang digunakan oleh Kesultanan Melayu Melaka. Sultan atau Yang Dipertuan Besar merupakan tonggak pemerintahan di Terengganu. Baginda dibantu oleh Yang Dipertuan Muda dan para pembesar. Baginda telah melantik puteranya bernama Zainal Abidin sebagai Yang Dipertuan Muda. Jawatan ini boleh dilihat melalui cap mohor yang digunakan oleh Zainal Abidin sebagai yang Dipertuan Muda bertarikh 1188 Hijrah, iaitu bersamaan 
1774 atau 1775 Masihi (Gallop, 2019). Para pembesar yang pernah membantu pemerintahan baginda termasuklah Bendahara, Tun Nara Wangsa, Orang Kaya Seri Wangsa, Dato Dungun dan Saudagar Raja (Sheppard, 1949; Andaya, B.W., 1978; MS 40320/11, f.68).

Sepanjang pemerintahannya, Sultan Mansur Shah I pernah berurusan dengan pelbagai kuasa luar seperti Belanda, Inggeris dan Siam. Bahkan baginda turut berinteraksi dengan kuasa tempatan seperti Bugis, Siak dan Kelantan. Sumber daripada Belanda telah memaklumkan bahawa Sultan Mansur Shah I pernah meminta bantuan Belanda yang berpusat di Melaka untuk membantu sepupunya, iaitu Sultan Johor, Sultan Sulaiman Badrul Alam Shah menentang Bugis sekitar tahun 1756 (Andaya, B.W., 1978). Namun demikian, tiada perjanjian yang wujud antara Terengganu dengan Belanda meskipun terdapat cubaan Belanda pada tahun 1756 dan 1758 untuk berunding bagi mendapatkan monopoli perdagangan lada di Terengganu (Andaya, B.W., 1976).

Kandungan warkah Sultan Mansur Shah I dalam Koleksi Warkah Francis Light banyak menyentuh hubungan Terengganu dengan Siam dan juga Inggeris sekitar tahun 1785 hingga 1794. Sultan Mansur Shah I mempamerkan kebijaksanaan baginda berpolitik ketika berhadapan dengan ancaman Siam dengan memohon bantuan kompeni Inggeris di Pulau Pinang. Inggeris yang baru sahaja menduduki Pulau Pinang pula sedang berusaha mengukuhkan kedudukannya sebagai pencabar penguasaan perdagangan Belanda di Selat Melaka. Oleh itu, perbincangan selanjutnya menganalisis bentuk hubungan yang terjalin antara Terengganu dengan Siam dan juga Inggeris.

\section{Hubungan Terengganu dan Siam}

Hubungan Terengganu dan Siam telah wujud secara langsung apabila Terengganu menghantar bunga emas kepada Siam. Peristiwa ini bermula apabila Sultan Mansur Shah I turut membantu Siam menyerang Legor, ataupun pada hari ini lebih dikenali dengan nama Nakhon Si Thammarat. Siam memberikan hadiah kepada Terengganu atas bantuan tersebut. Sekitar tahun 1781, Sultan Mansur Shah I mula menghantar bunga emas ke Bangkok pada setiap tiga tahun sebagai tanda persahabatan (Misbaha, 1992).

Meskipun demikian, pemberian bunga emas itu telah disalah anggap oleh Siam sebagai tanda bahawa Terengganu berada di bawah naungannya. Dalam warkah Sultan Mansur Shah I bertarikh 15 Syaaban 1201 bersamaan 2 Jun 1787, baginda 
mengadu kepada Francis Light berkaitan dengan tindakan Raja Siam yang meminta Sultan Mansur Shah I ataupun anakandanya untuk datang mengadap Raja Siam. Bukan setakat Sultan Terengganu, bahkan Sultan Kedah dan Patani juga turut dipanggil untuk mengadap Raja Siam (MS 40320/11, f.69).

Sultan Mansur Shah I enggan datang mengadap sembah kepada Raja Siam yang berada di Singgora kerana tindakan tersebut merupakan suatu pengiktirafan terhadap penguasaan Siam terhadap kedaulatan Terengganu. Hubungan antara Terengganu dan Siam hanyalah hubungan persahabatan melalui pemberian bunga emas dan perak. Sepanjang pemerintahan Sultan Mansur Shah I, baginda tidak pernah lagi datang mengadap sembah kepada Raja Siam. Baginda menyatakan kepada Francis Light:

... adapun akan hal surat Raja Siam kepada kita maka kita memberi jawab balas surat Raja Siam itu maka kata kita tiada istiadat daripada beberapa zaman mengadap Raja Siam itu melainkan sekadar mengantarkan bunga emas dan perak sahaja ...

Bukan sekadar itu, baginda juga mengaitkan keturunannya yang berasal daripada kesultanan Johor yang tidak pernah datang mengadap sembah kepada Raja Siam (MS 40320/11, f.68). Baginda membuat keputusan untuk tidak memenuhi permintaan mengadap oleh Raja Siam dan perlu bersedia untuk berhadapan dengan sebarang tindak balas daripada Siam.

Selepas Sultan Mansur Shah I menolak permintaan mengadap Raja Siam, Raja Siam terus memberikan tekanan kepada Sultan Terengganu dengan meminta baginda menyediakan 100 laras meriam untuk diserahkan kepada Siam. Jumlah itu merupakan jumlah yang besar dan memerlukan modal kewangan yang tinggi untuk membelinya. Baginda sekali lagi tidak dapat memenuhi permintaan Raja Siam. Oleh itu, Sultan Mansur Shah I menjangkakan bahawa Siam akan menyerang Terengganu seperti yang berlaku kepada Patani.

Baginda menegaskan:

... maka sangatlah beratnya kehendak Raja Siam itu kepada kita maka kita pun sangatlah ketakutan akan Raja Siam itu maka kita pun berkukuh negeri hendak melawan Raja Siam itu ... 
Sultan Mansur Shah I berusaha untuk mengukuhkan pertahanan negerinya dengan meminta bantuan Francis Light untuk menolong Terengganu menjalinkan hubungan diplomatik dengan kompeni Inggeris yang berpusat di Benggala. Apabila hubungan ini wujud, baginda berharap kompeni Inggeris dapat membantu mempertahankan Terengganu sekiranya diserang oleh Siam. Oleh itu, baginda meminta Francis Light menghantar kapal perang untuk meronda sekitar perairan Terengganu sekitar bulan April dan Mei 1788 kerana dijangkakan serangan Siam akan berlaku pada masa tersebut (MS 40320/11, f.68 dan f.85).

Selepas tentera Siam datang menyerang dan mengalahkan Patani, mereka akhirnya meninggalkan Patani dan Singgora untuk pulang semula ke tempat mereka dengan membawa ramai tawanan dari Patani. Perkara ini amat melegakan Sultan Mansur Shah I kerana ancaman serangan daripada tentera Siam sudah berkurangan. Baginda memaklumkan dalam warkahnya bertarikh 15 Syaaban 1201 bersamaan 2 Jun 1787:

... maka dengan tolong Allah dan rasul-Nya Siam itupun pulang ia ke negerinya maka banyaklah dibawanya orang Patani yang dapat akan dia itu ke negerinya ...

(MS 40320/11, f.69)

Walaupun hubungan Terengganu dengan Siam agak tegang, Sultan Mansur Shah I tetap meneruskan penghantaran bunga emas dan perak kepada Siam. Dalam warkah bertarikh 12 Jamadil Awal 1206 bersamaan 7 Januari 1792, Sultan Mansur Shah I memaklumkan bahawa bunga emas dan perak serta hadiah lain yang dihantar dari Terengganu telah ditolak oleh Raja Legor untuk disampaikan kepada Raja Siam. Baginda memaklumkan kepada Francis Light:

... maka pada tahun ini kita antar pergi bunga emas bunga perak bagaimana istiadat yang selama-lamanya maka sampai ke Legor Raja Legor tiadalah mau terima bunga emas itu membawa masuk kepada Raja Siam maka dikehendakinya yang tiada patut atas kita maka tiadalah kuasa kita mengadakannya seperti kehendaknya ...

(MS 40320/11, f.97)

Berdasarkan warkah ini, penghantaran bunga emas dan perak dari Terengganu kepada Raja Siam perlu dilakukan menerusi Raja Legor. Pada tahun tersebut, Raja Legor telah menolak untuk membawa masuk bunga emas dan perak serta mengambil 
kesempatan dengan membuat permintaan yang sukar untuk dipenuhi oleh Sultan Terengganu. Permintaan Raja Legor itu tidak dimaklumkan secara terperinci dalam warkah baginda.

Kerajaan Legor yang berpusat di Nakhon Si Thammarat merupakan sebuah kerajaan yang menyokong pemerintahan Raja Siam, iaitu Raja Rama I daripada Dinasti Cakri yang berpusat di Bangkok. Kerajaan Legor berfungsi sebagai orang tengah yang mengawal hubungan antara kesultanan Terengganu dan Siam. Apabila Raja Legor menolak pemberian bunga emas dan perak daripada Terengganu kepada Raja Siam, Sultan Mansur Shah I tidak mampu untuk berbuat apa-apa selain bersedia untuk menerima serangan daripada Siam seperti yang pernah dilakukan oleh Siam terhadap Patani.

Sultan Mansur Shah I memaklumkan kepada Francis Light dalam warkahnya bertarikh 3 Safar 1207 bersamaan 20 September 1792:

... kita dengan Siam ini lagi bergaduhan tiadalah tentu baiknya dan jahatnya maka kita pun sudah beri pergi bunga emas dan bunga perak serta dengan hadiahnya maka belum datang jawabnya maka pada tahun ini datang Siam ke Patani dipukulnya Patani habislah binasa pecah belah dan bunuhnya Orang Besar-besar Patani ...

(MS 40320/11, f.67)

Kedudukan Terengganu sebagai pelabuhan Melayu dan bukannya di bawah Siam terdapat dalam catatan Francis Light pada tahun 1789 (Wurtzburg, 1938). Serangan Siam terhadap Terengganu akan menambahkan lagi konflik antara Siam dengan kesultanan Melayu. Namun begitu, sehingga Sultan Mansur Shah I mangkat pada awal tahun 1794, Raja Siam tidak pernah datang menyerang Terengganu.

\section{Hubungan Terengganu dan Kompeni Inggeris}

Terengganu telah lama menjadi pelabuhan persinggahan bagi kapal-kapal Inggeris dalam pelayaran ke Siam, Manila dan China. Dalam kalangan pelayar Eropah, pelayar Inggeris sudah lama mempunyai pengetahuan berkaitan dengan kedudukan pelabuhan Terengganu (Dunmore, 1973).

Pada April 1764, Sultan Mansur Shah I menghantar surat meminta bantuan pembelian senjata kepada kapten kapal Inggeris yang singgah di Terengganu dalam perjalanan ke Manila dan China. Dua bulan kemudian, Kapten Joseph Jackson, ketika dalam pelayarannya ke Canton bertemu dengan Sultan Terengganu pada 14 Jun 
1764 (Sivachanralingam, 2000). Pertemuan tersebut adalah untuk membincangkan hasrat kompeni Inggeris yang berpusat di Kolkata untuk menduduki Pulau Redang atau Dungun. Meskipun akhirnya tiada penempatan Inggeris yang dapat dibina di Terengganu, pertemuan tersebut menunjukkan minat Inggeris yang dapat mengesan potensi Pulau Redang untuk dimajukan sebagai pelabuhan. Penguasaan terhadap pulau itu akan memberikan kelebihan kepada Inggeris untuk menguasai laluan perdagangan ke Manila, Siam, Vietnam dan China.

Bermula pada tahun 1785, Francis Light yang berada di Pulau Pinang sering berutus surat dengan Sultan Mansur Shah I melalui nakhoda kapal yang membawa barang dagangan. Sultan Mansur Shah I berusaha untuk menjalinkan hubungan diplomatik dengan kompeni Inggeris atas faktor politik dan ekonomi. Inggeris diperlukan untuk membantu Terengganu daripada serangan Siam yang telah pun menyerang Patani. Baginda menjadikan Francis Light sebagai perantara untuk baginda berhubung dengan kompeni Inggeris yang berpusat di Benggala.

Sultan Mansur Shah I memberikan beberapa justifikasi untuk kompeni Inggeris menjalinkan hubungan diplomatik dengan Terengganu. Baginda menyatakan:

... kerana negeri Terengganu itu tempat segala kapitan Inggeris singgah mencari bekal barang yang kurang dan jikalau sudah hasil pekerjaan ini bolehlah berhubung kompeni Inggeris pada jalan perniagaan barang yang jadi patut kepada anak kita yang jadi untung kepada kompeni dengan kita boleh kita kerjakan ...

(MS 40320/11, f.69)

Berdasarkan catatan dalam warkah tersebut, baginda menyatakan bahawa Terengganu merupakan tempat persinggahan pelayar Inggeris sejak sekian lama untuk mendapatkan bekalan pelayaran. Sekiranya hubungan kompeni Inggeris dengan Terengganu dapat dipersetujui, kompeni Inggeris akan mendapat kelebihan berdagang di Terengganu melibatkan keuntungan yang tinggi.

Cubaan Sultan Mansur Shah I menjalinkan hubungan diplomatik dengan kompeni Inggeris bukanlah hanya berlaku melalui Francis Light. Sebelum itu, baginda pernah meminta bantuan kapitan Hob. Umum mengetahui bahawa Inggeris sememangnya sedang mempertimbangkan beberapa penempatan sebagai pusat perdagangan Inggeris di Alam Melayu termasuklah Pulau Pinang. Pertimbangan ini bukan hanya dilihat daripada aspek ekonomi, tetapi termasuklah aspek politik dan pertahanan.

Sultan Mansur Shah I memaklumkan dalam warkah baginda bertarikh 15 Syaaban 1201 bersamaan 2 Jun 1787: 
... daripada dahulunya pun sudah kita bicarakan kepada segala kapitan Inggeris maka tiada juga bertemu dengan orang yang menjalani seperti maksud kita kerana dahulunya pun ada kita minta tolong kepada kapitan Hob akan menyampaikan permintaan kita kepada kompeni Benggala maka tiada juga sampai ...

(MS 40320/11, f.69)

Catatan Sultan Mansur Shah I memberikan petunjuk bahawa permintaan Terengganu untuk menjalinkan hubungan diplomatik dengan kompeni Inggeris telah berlangsung lebih awal dan usaha ini diteruskan lagi melalui Francis Light ketika beliau berada di Pulau Pinang.

Sultan Mansur Shah I sentiasa mendesak Francis Light untuk segera mendapatkan keputusan daripada kompeni Inggeris berkaitan dengan hubungan diplomatik dengan Terengganu. Desakan ini berkaitan dengan kebimbangan baginda terhadap ancaman serangan daripada Siam yang boleh menyerang Terengganu pada bila-bila masa. Pada 18 Zulkaedah 1201 bersamaan 31 Ogos 1787, Sultan Mansur Shah I menghantar warkah agar keputusan kompeni Inggeris dapat diketahui selewatlewatnya pada bulan Mei 1788. Baginda menyatakan:

... jikalau sudah qabul daripada perkiraan kita dengan kompeni itu maka hendaklah anak kita antarkan bendera serta cap jikalau boleh dahulu daripada bulan Mayu kerana kita sangatlah dalam gundah ...

(MS 40320/11, f.85)

Sultan Mansur Shah I menunjukkan kesungguhannya berbaik dengan kompeni Inggeris dengan menjemput wakil kompeni Inggeris untuk datang ke Terengganu pada bulan April 1788 berserta James Glass. Dalam warkah baginda bertarikh 6 Safar 1201 bersamaan 16 November 1787, baginda memaklumkan:

... telah sangatlah harap seri paduka ayahanda akan penolong anak kita sampai Jaga-jaga dan bendera serta dengan orang besar barang seorang bersama-sama anak kita itu Kapitan Glass datang pada bulan empat juga adanya ...

(MS 40320/11, f.68)

Berdasarkan desakan dan kesungguhan baginda, Francis Light menyatakan sokongannya kepada Gabenor-Jeneral Inggeris di Benggala dalam surat bertarikh 10 Januari 1788 untuk membuka gudang di Kuala Terengganu di bawah seliaan James 
Glass. Di samping itu, Francis Light juga bersetuju dengan pandangan Sultan Mansur I berkaitan dengan penghantaran kapal perang ke Terengganu untuk menakutkan Siam daripada menyerang Terengganu (Bassett, 1965).

Walau bagaimanapun, kompeni Inggeris telah pun bersetuju dengan polisi untuk tidak campur tangan dalam urusan dalaman kesultanan Melayu termasuklah negeri Terengganu, Perak dan Selangor. Kedatangan wakil Sultan Mansur Shah I ke Benggala pada bulan Februari 1788 untuk membincangkan kerjasama diplomatik dengan kompeni Inggeris adalah sia-sia kerana cadangan itu telah ditolak berdasarkan polisi tersebut (Bassett, 1965).

Selepas daripada itu, tiada lagi kedengaran perbincangan mengenai permintaan Terengganu untuk menjalinkan hubungan diplomatik dengan kompeni Inggeris dalam warkah-warkah Sultan Mansur Shah I. Polisi yang ditetapkan oleh Gabenor Jeneral Inggeris terhadap kesultanan Melayu tidak dapat diubah. Hubungan Sultan Mansur Shah I dengan Francis Light di Pulau Pinang tetap diteruskan melalui hubungan perdagangan.

Bagi melindungi perdagangan Inggeris di Terengganu, Francis Light bersetuju untuk menghantar kapal perang Inggeris, tetapi kos penghantarannya mestilah ditanggung oleh Terengganu (MS 40320/11, f.68 dan f.85). Kos ini dibiayai melalui pembelian lada oleh Inggeris di Terengganu dengan harga yang lebih murah, iaitu 12 rial sepikul berbanding harga biasa yang mencecah 15 rial sepikul. Melalui kaedah ini, kompeni Inggeris mendapat keuntungan kerana dapat membeli lada dengan harga murah.

Malangnya, apabila kapal tersebut dihantarke Terengganu, baginda memaklumkan bahawa kapal itu ialah kapal yang menyerupai kapal perdagangan dan bukannya kapal perang. Walaupun kapal yang dihantar itu tidak mengikut spesifikasi seperti yang diminta, baginda tetap memenuhi janjinya untuk menjual lada dengan harga yang murah sebagai kos penghantaran kapal itu (MS 40320/11, f.98). Akibat menjual lada dengan harga yang murah, Terengganu dilaporkan mengalami kerugian lebih daripada 20000 rial pada tahun tersebut. Selain bantuan kapal peronda, Terengganu juga dapat mengukuhkan pertahanannya dengan membeli senjata seperti senapang, belerang, ubat bedil, peluru dan meriam (MS 40320/11, f.67 dan f.71).

Di samping itu, Francis Light turut mengambil peluang daripada Sultan Terengganu dengan meminta baginda membekalkan maklumat berkaitan dengan Perancis dan Belanda. Baginda melaporkan terdapat maklumat menyatakan bahawa orang Perancis pernah singgah sebentar di pelabuhan Kochi di Vietnam, tetapi mereka tidak tinggal lama di sana. Maklumat berkaitan dengan Belanda tidak 
diberikan secara terperinci, tetapi baginda menggunakan pendekatan diplomatik dengan menyatakan bahawa Francis Light memiliki maklumat yang lebih banyak lagi berkaitan dengan Belanda:

... anak kita minta periksa tentukan tempat negeri Wolanda di sebelah timur ini dan besar kotanya dan banyak orangnya itu lebih tahu anak kita akan tempatnya dan negerinya dan besar kotanya dan banyak orangnya di sebelah Timur ini ...

(MS 40320/11, f.85)

Bagi mengukuhkan kedudukan perdagangan Inggeris di Pulau Pinang, Francis Light meminta agar Sultan Terengganu memujuk orang-orang Bugis yang berada di pelabuhan Terengganu untuk berdagang di Pulau Pinang. Francis Light berhadapan dengan masalah kekurangan pedagang Bugis ke Pulau Pinang kerana dasar monopoli Belanda yang menguasai Selat Melaka sehingga menyebabkan pedagang Bugis menghadapi kesukaran untuk berdagang ke Pulau Pinang (Bassett, 1965).

Selain itu, Sultan Mansur Shah I turut melaporkan kepada Francis Light masalah dalaman yang baginda hadapi. Sebagai contoh, baginda berhadapan dengan rancangan serangan oleh orang Siak terhadap Terengganu. Dalam warkah baginda bertarikh 14 Zulkaedah 1203 bersamaan 6 Ogos 1789, baginda memaklumkan bahawa pasukan tentera Siak sudah pun berkumpul di Pulau Redang (MS 40320/11, f.71). Kehadiran tentera Siak bersama-sama 30 buah perahu ini diketuai oleh Syed Ali. Untuk menyelesaikan isu ini, baginda merancang untuk menyerang kedudukan orang Siak di Pulau Redang pada 15 Zulkaedah 1203 bersamaan 7 Ogos 1789 dengan bala tentera baginda sendiri. Walau bagaimanapun, peperangan antara Terengganu dan Siak ini berjaya dielakkan hasil rundingan antara Sultan Mansur Shah I dengan Syed Ali (Sheppard, 1949).

Pelabuhan Pulau Pinang sering menerima kapal-kapal yang datang dari India. Oleh itu, Sultan Terengganu meminta bantuan Francis Light untuk menumpangkan bakal-bakal haji dari Terengganu ke pelabuhan India seperti pelabuhan Surati, Malibari ataupun Mumbai (MS 40320/11, f.75 dan f.77). Baginda juga meminta bantuan untuk menumpangkan keluarga syeikh Arab pulang ke tanah Arab (MS 40320/11, f.80 dan f.100). Oleh itu, kapal Inggeris digunakan bukan sahaja untuk menolong menumpangkan bakal-bakal haji ke Mekah, tetapi juga orang-orang Arab untuk pulang ke negara mereka.

Sebagai tanda persahabatan antara Terengganu dengan Pulau Pinang, Sultan Terengganu sering mengirimkan hadiah berupa kain besar buatan Terengganu. Pasaran kain di Terengganu memberikan risiko tinggi kepada pedagang kerana 
pembeli tempatan hanya memilih kain berkualiti tinggi sahaja (Dunmore, 1973). Maka, tidak menghairankanlah sekiranya kain besar Terengganu dijadikan sebagai hadiah daripada Sultan Mansur Shah I kerana keistimewaan kain ini berbanding kain yang dibawa masuk dari luar Terengganu.

\section{Aspek Ekonomi}

Maklumat umum berkaitan dengan ekonomi pada zaman Sultan Mansur Shah I boleh ditemui dalam laporan oleh pelayar Eropah seperti pelayar Perancis, Inggeris dan rekod daripada Belanda. Pedagang Eropah menjual komoditi seperti opium, kain berkualiti tinggi dari India dan senjata seperti meriam dan rentaka. Mereka pula dapat membeli komoditi seperti timah, lada, lilin, rotan dan emas. Perdagangan dijalankan menggunakan sistem mata wang dan barter (Dunmore, 1973). Melalui warkah Sultan Mansur Shah I, maklumat yang lebih mendalam berkaitan dengan kegiatan perdagangan di Terengganu boleh ditemui yang melibatkan komoditi, jaringan perdagangan dan peraturan yang mesti diikuti oleh pedagang di Terengganu.

Pada zaman Sultan Mansur Shah I, masyarakat Terengganu bekerja sebagai pedagang, nelayan, penternak dan petani. Mereka menjual hasil tempatan kepada pedagang dari Eropah, Siam dan Cina yang singgah di Terengganu. Sultan Mansur Shah I mengakui bahawa Terengganu sering menerima pelayar Inggeris yang singgah untuk mengambil bekalan air dan makanan (MS 40320/11, f.69).

Terengganu memiliki kapal maritim bagi perdagangan jarak jauh. Kapal dari Terengganu mampu berlayar hingga ke India dan China. Di India, kapal ini singgah di pelabuhan seperti Benggala, Mumbai dan Madras (MS 40320/11, f.100). Pelabuhan Terengganu juga mempunyai hubungan dagang secara langsung dengan pelabuhan Kwangtung yang terletak di wilayah Guangzhou (MS 40320/11, f.74). Menurut laporan Francis Light, China ialah rakan dagang utama Terengganu (Wurtzburg, 1938). Selain itu, Terengganu telah lama mempunyai hubungan dagang dengan Sumatera, Jawa, Borneo dan kepulauan Maluku (Dunmore, 1973). Jaringan pelayaran kapal Terengganu dapat dikesan berlayar ke pelabuhan Pulau Pinang, Kedah, Palembang, Jawa, Susuh, Patani, Siam, Kemboja, Mempawah, Pontianak, Sambas dan Brunei (MS 40320/11, f.87).

Sejak tahun 1769 , pelayar Perancis memaklumkan bahawa pelabuhan Terengganu masyhur dengan komoditi seperti timah, lilin, rotan, lada dan cengkih (Dunmore, 1973). Menurut laporan Francis Light, jumlah eksport tahunan pelabuhan Terengganu mencecah 30000 dolar Sepanyol (Wurtzburg, 1938). Timah dan lada 
diambil dari Palembang dan dibawa ke Terengganu untuk dieksport ke pasaran China bersama-sama komoditi lain seperti rotan dan kapas. Perdagangan lada di Terengganu mencecah 13000 hingga 17000 pikul setahun (Bassett, 1965). Setiap kapal perdagangan mampu membawa antara 4000 hingga 6000 pikul lada. Harga sepikul lada di Terengganu dijual sekitar 14 rial dan meningkat sehingga 22 rial sepikul di China (MS 40320/11, f.67).

Opium merupakan komoditi yang bernilai tinggi di Terengganu. Pada tahun 1769, pelayar Perancis merekodkan bahawa opium dapat dijual di Terengganu antara 200 hingga 350 rial sepeti (Dunmore, 1973). Bermula pada tahun 1773, pengeluaran opium semakin bertambah banyak di India dan akhirnya perusahaan ini dikuasai oleh kompeni Inggeris melalui kilangnya di Patna dan Baneras dan dieksport ke China (Bailey \& Truong, 2001). Oleh sebab pelabuhan Terengganu mempunyai jaringan perdagangan secara langsung dengan China, opium merupakan komoditi yang mudah dijual dan mendapat permintaan tinggi.

Opium yang dihasilkan di India mempunyai pelbagai kualiti. Sultan Mansur Shah I sering membeli opium jenis Patna dan Baneras. Bahan ini dibeli dengan harga 335 rial sepeti dan dibawa masuk sehingga 400 peti ke Terengganu (MS 40320/11, f.80 \& f.83). Baginda memilih opium jenis Patna dan Baneras kerana ketinggian kualitinya berbanding opium jenis lain seperti Malwa ataupun Parsi. Tambahan pula, pasaran di China mengutamakan opium jenis Patna dan Baneras (Parker, 1888). Opium yang dijual dikenakan cukai sebanyak sepuluh peratus oleh sultan (Dunmore, 1973). Peraturan perdagangan di Terengganu tidak membenarkan opium dijual melainkan kepada saudagar yang ditentukan oleh sultan untuk memudahkan urusan pungutan cukai. Akibat pernah melanggar peraturan ini, Kapitan Clark telah dihalang untuk datang lagi berdagang di Terengganu (MS 40320/11, f.76).

Barangan makanan asas yang mendapat permintaan tinggi daripada penduduk tempatan ialah beras dan ikan. Bekalan ikan dapat dipenuhi dengan mudah berdasarkan jumlah perahu-perahu nelayan yang memenuhi sungai Terengganu (Dunmore, 1973). Walau bagaimanapun, Terengganu bukanlah negeri utama pengeluar beras. Beras terpaksa dibawa masuk dari pelabuhan Patani dan Kedah yang merupakan negeri yang menghasilkan beras dengan banyak. Sultan Mansur Shah I pernah membeli beras di Pulau Pinang sehingga 200 koyan beras dengan harga 80 rial bagi sekoyan beras (MS 40302/11, f.67).

Harga dan kualiti sesuatu komoditi memainkan peranan penting di Terengganu. Contohnya, kain dari India sukar untuk dijual melainkan kain yang berkualiti tinggi dengan corak warna tertentu (Dunmore, 1973). Komoditi yang diletakkan dengan harga yang terlampau tinggi juga tidak terjual. Misalnya, Francis 
Light pernah menghantar komoditi untuk dijual pada harga 10000 rial dan didapati tidak laku kerana terlampau mahal. Untuk mengelakkan kerugian, Saudagar Nasruddin terpaksa menurunkan harganya sehingga 5000 rial dan beliau masih lagi menghadapi kesukaran untuk menghabiskan jualannya dengan harga murah tersebut (MS 40320/11, f.92).

Bagi membantu urusan perdagangan Sultan Mansur Shah I, baginda melantik Saudagar Raja yang bernama Nasruddin. Peranan Saudagar Raja amat penting untuk menguruskan perdagangan baginda yang melibatkan import dan eksport komoditi di Terengganu. Sultan turut terlibat dalam perkongsian modal dan Saudagar Nasruddin diberikan kebebasan untuk menguruskan modal baginda. Saudagar Nasruddin dilaporkan pernah berkongsi modal dengan James Glass, Francis Light dan Farley bagi tujuan pembelian kapal (MS 40320/6, 51, MS 40320/11, f.88 \& f.108). Kejayaan perdagangan di Terengganu banyak dibantu oleh Saudagar Nasruddin. Selepas kematiannya pada 18 Disember 1791, tempat beliau telah digantikan oleh saudaranya, iaitu Nakhoda Parya Tambi. Sultan Terengganu bimbang kemerosotan perdagangan di Terengganu selepas kematian Saudagar Nasruddin sehingga baginda memohon kepada Francis Light agar hubungan perdagangan Terengganu dan Pulau Pinang diteruskan seperti biasa meskipun selepas ketiadaan Saudagar Nasruddin (MS 40320/11, f.97).

Selain terlibat dalam perdagangan, Saudagar Raja juga terlibat membantu Sultan Terengganu dalam perhubungan politik antarabangsa kerana beliau mempunyai jaringan perdagangan yang luas. Contohnya, pada tahun 1787, di samping membawa barang dagangan ke Pulau Pinang, Saudagar Nasruddin bersama-sama Orang Kaya Seri Wangsa juga diarah bertemu Francis Light untuk membincangkan masalah hubungan Terengganu dengan Siam (MS 40320/11, f.68). Saudagar Nasruddin dilaporkan pernah bertemu Gabenor Jeneral Inggeris di Benggala pada tahun 1788 (Barbara, 1978).

Selain Saudagar Raja, Sultan Mansur Shah I juga memiliki ramai nakhoda kapal yang turut membantu baginda menjalankan urusan perdagangan. Nakhoda bukan sahaja perlu mengetahui laluan pelayaran ke sesuatu tempat, tetapi mereka juga perlu menguasai bahasa dan adat tempatan. Bagi perdagangan ke India, baginda mengutus Sayid Abdullah Qumasyi dan Nakhoda Bawa (MS 40320/11, f.78). Kapal yang dihantar ke pelabuhan di alam Melayu pula diuruskan oleh nakhoda seperti Wan Muhammad, Nakhoda Parya Tambi, Nakhoda Naina, Syeikh Muhammad dan Nakhoda Sitam.

Penguatkuasaan undang-undang penting untuk memastikan keselamatan 
pedagang terjamin dan seterusnya menarik lebih ramai pedagang luar datang ke Terengganu. Terdapat beberapa contoh penguatkuasaan undang-undang bunuh yang berlaku pada zaman Sultan Mansur Shah I. Pada tahun 1769, pedagang Perancis memuji tindakan pantas pembesar Terengganu yang menangkap dan menjatuhkan hukuman bunuh terhadap penjenayah yang melakukan kesalahan merompak dan membunuh (Dunmore, 1973). Pada Disember 1791, Sayid Abdullah bin Sayid Idrus dan dua orang rakannya yang mengamuk dan membunuh Saudagar Nasruddin telah segera ditangkap dan dijatuhkan hukuman mati (MS 40320/11, f.97).

Pedagang luar yang ingin bergerak masuk ke dalam negeri Terengganu tertakluk pada kebenaran daripada sultan. Kebenaran juga mesti diperoleh sebelum sesebuah kapal luar boleh masuk untuk dibaiki di sungai Terengganu. Seorang kapitan Inggeris, iaitu Kapitan Canning telah melanggar peraturan ini dengan menceroboh masuk ke sebuah kampung di Terengganu pada waktu malam. Kapitan itu menggunakan alasan untuk mencari kelasinya yang melarikan diri. Akibatnya, beliau telah ditikam di sebuah rumah sehingga cedera. Sultan Mansur Shah I murka terhadap kapitan itu dan meminta Francis Light mengambil tindakan atas kesalahan yang telah dilakukannya (MS 40320/11, f.74).

Kemahiran berbahasa Melayu dan memahami peraturan tempatan merupakan kemahiran yang penting bagi setiap pedagang luar yang datang ke Terengganu. Mereka juga perlu jujur ketika menjalankan urusan perdagangan di Terengganu. Kebanyakan pedagang Inggeris yang berdagang di Terengganu menguasai bahasa Melayu dan adat tempatan dengan baik. Contohnya, Sultan Terengganu memuji Kapitan Carnegie kerana mempunyai kemahiran bahasa Melayu dan juga seorang yang berbudi bahasa (MS 40320/11, f.80). Kapitan Dunlop tidak disukai oleh Saudagar Nasruddin kerana sikapnya yang tidak jujur dan tidak memahami adat resam Raja Melayu (MS 40320/11, f.88).

\section{KESIMPULAN}

Warkah-warkah Sultan Mansur Shah I telah memberikan gambaran yang jelas berkaitan suasana politik dan ekonomi Terengganu sekitar tahun 1785 hingga tahun 1794. Hubungan Terengganu dengan Siam agak tegang kerana siri ancaman serangan dari Siam terhadap Terengganu. Baginda pernah dipanggil mengadap oleh Raja Siam di Singgora, namun baginda bertegas untuk tidak datang mengadap kerana Terengganu bukannya negeri di bawah jajahan Siam. Kesultanan Terengganu 
mempunyai kedaulatan sama seperti kesultanan Johor yang tidak perlu tunduk kepada perintah Siam. Baginda meneruskan penghantaran bunga emas dan perak kepada Siam sebagai lambang persahabatan. Sehingga akhir hayat baginda, Terengganu tidak diserang oleh Siam seperti yang berlaku kepada kesultanan Patani meskipun Siam telah beberapa kali memberikan amaran untuk menyerang Terengganu.

Hubungan Terengganu dengan Inggeris telah dimulakan lebih awal lagi sebelum kedatangan Francis Light ke Pulau Pinang. Sultan Mansur Shah I mengharapkan agar wujudnya hubungan diplomatik dengan Inggeris bagi membantu baginda menghadapi serangan Siam. Walau bagaimanapun, hubungan tersebut tidak dapat diteruskan kerana dasar kompeni Inggeris untuk tidak campur tangan terhadap masalah dalaman kesultanan Melayu. Meskipun demikian, hubungan Terengganu dan Inggeris diteruskan atas dasar perdagangan. Jaringan perkapalan Francis Light turut digunakan untuk membantu bakal haji dari Terengganu pergi ke Mekah melalui kapal di Pulau Pinang dan India.

Dalam aspek ekonomi, Terengganu menjadi pelabuhan utama yang menghubungkan alam Melayu dengan pelabuhan China. Terengganu juga terkenal sebagai pelabuhan persinggahan bagi pedagang Eropah. Komoditi utama di Terengganu ialah opium dan lada. Selain Pulau Pinang yang membekalkan opium dan beras, Palembang menjadi rakan dagang utama untuk membekalkan bijih timah dan lada. Perdagangan Sultan Mansur Shah I diuruskan oleh Saudagar Raja, iaitu Saudagar Nasruddin. Beliau melaksanakan kaedah perkongsian modal dengan pedagang Inggeris bagi mendapatkan lebih banyak keuntungan. Di samping itu, Terengganu menjadi pelabuhan yang sesuai untuk pedagang Inggeris datang berdagang kerana kemahiran mereka berbahasa Melayu dan memahami adat dan peraturan tempatan.

Kesimpulannya, kandungan warkah-warkah Sultan Mansur Shah I telah membuktikan kedudukannya sebagai sumber tempatan yang berautoriti dalam memberikan maklumat yang lebih mendalam berkaitan dengan politik dan perdagangan di Terengganu pada hujung abad ke-18.

\section{PENGHARGAAN}

Penulis merakamkan setinggi-tinggi penghargaan kepada Susannah Rayner dan Erich Kesse daripada bahagian Arkib dan Koleksi Khas, Perpustakaan School of Oriental and African Studies, University of London atas bantuan dan perkongsian salinan digital ketika menjalankan kajian terhadap manuskrip MS 40320 “The Light Letters”. 


\section{RUJUKAN}

A. Samad Ahmad. (1979). Sulalatus Salatin (Sejarah Melayu). Kuala Lumpur: Dewan Bahasa dan Pustaka.

Abdullah Zakaria Ghazali. (1997). Istana dan Politik Johor 1835-1885. Kuala Lumpur: Yayasan Penataran Ilmu.

Abdullah Zakaria Ghazali. (2006). Surat-surat Baginda Omar. Rogayah A. Hamid dan Mariyam Salim (Eds.). Kesultanan Melayu Terengganu (pp. 51-74). Kuala Lumpur: Dewan Bahasa dan Pustaka.

Abdullah Zakaria Ghazali. (2012) Politik dan Pemerintahan: Tiga Abad Kesultanan Terengganu. Abdul Rahman Embong (Ed.). Terengganu Merentasi Tiga Abad (pp. 75101). Terengganu: Yayasan Diraja Sultan Mizan.

Ahmat Adam. (2009). Letters of Sincerity: The Raffles Collection of Malay Letters (17801824): A Descriptive Account with Notes and Translation, Kuala Lumpur: Malaysian Branch of the Royal Asiatic Society.

Ahmat Adam. (2017). The New \& Correct Date of the Terengganu Inscription. Petaling Jaya: Strategic Information and Research Development Centre.

al-Attas, Syed Muhammad Naquib. (1970). The Correct Date of the Terengganu Inscription. Kuala Lumpur: Museum Department.

Andaya, B.W. (1976). An Examination of Sources Concerning the Reign Of Sultan Mansur Syah of Terengganu (1741-1793), With Special Reference to the Tuhfat al-Nafis. Journal of the Malaysian Branch of the Royal Asiatic Society, 49(2), (230), 80-106.

Andaya, B.W.. (1978). The Indian Saudagar Raja (The King's Merchant) in Traditional Malay Courts. Journal of the Malaysian Branch of the Royal Asiatic Society, 51(1), (233), 12-35.

Andaya, Leonard, Y. (2012) Features of Early Terengganu History. Abdul Rahman Embong (Ed.), Terengganu Merentasi Tiga Abad (pp. 37-52). Terengganu: Yayasan Diraja Sultan Mizan.

Arba'iyah Mohd. Noor. (2006). Naskhah salasilah Sultan Omar dan Salasilah Kesultanan Terengganu. Rogayah A. Hamid dan Mariyam Salim (Eds.), Kesultanan Melayu Terengganu (pp. 1-50). Kuala Lumpur: Dewan Bahasa dan Pustaka.

Bailey, Warren and Truong, Lan. (2001). Opium and Empire: Some Evidence from Colonialera Asian Stock and Commodity Markets. Journal of Southeast Asian Studies, 32(2), 173-193.

Bassett, David Kenneth. (1965). Anglo-Malayrelations, 1786-1795. Journal of the Malaysian Branch of the Royal Asiatic, 38(2), (208), 183-212.

Clifford, Hugh. (1938). Expedition to Trengganu and Kelantan. Kuala Lumpur: Federated 
Malay States Government Press.

Dunmore, John (1973) French Visitors toTrengganu in the Eighteenth Century. Journal of the Malaysian Branch of the RoyalAsiatic Society, 46(1), (223), 144-159.

Gallop, Annabel Teh. (1994). The Legacy of the Malay Letter. London: British Library.

Gallop, Annabel Teh. (2019). Malay Seals from the Islamic World of Southeast Asia. Singapore: NUS Press.

Gibson-Hill, C., Skeat, W., \& Laidlaw, F. (1953). The Cambridge University Expedition to the North-Eastern Malay States, and to Upper Perak, 1899 - 1900. Journal of the Malayan Branch of the Royal Asiatic Society, 26(4) (164), 1-174.

Hamilton, Alexandar. (2013). A New Account of the East Indies: Being the Observations and Remarks of Capt. Alexander Hamilton. Cambridge: Cambridge University Press.

Jelani Harun. (2017). Zainal Abidin III Biografi Sultan Yang Adil dan Alim. Kuala Lumpur: Dewan Bahasa dan Pustaka.

Narizan Abdul Ghani. (2006). Warkah-warkah Istana Negeri Terengganu: Tujuan dan Kandungan, dalam Rogayah A. Hamid dan Mariyam Salim (Ed.), Kesultanan Melayu Terengganu (pp. 75-101). Kuala Lumpur: Dewan Bahasa dan Pustaka.

Kassim Ahmad. (1975). Hikayat Hang Tuah. Kuala Lumpur: Dewan Bahasa dan Pustaka.

Khoo Kay Kim. (1984). Kuala Terengganu: Pusat Perdagangan Antarabangsa. Abdullah Zakaria Ghazali (Ed.), Terengganu Dahulu dan Sekarang (pp. 57-73). Kuala Lumpur: Persatuan Muzium Malaysia.

Marriott, H. (1916, May). A Fragment of the History of Trengganu and Kelantan. Journal of the Straits Branch of the Royal Asiatic Society, 72, 3-23.

Marsden, William. (1812). A Grammar of the Malayan Language with an Introduction and Praxis. London: Coxand Baylis.

McNab, Robert. (1914). Historical Records of New Zealand (Vol. I). Wellington: John Mackay.

Misbaha. (1992). Sejarah Darul Iman. Terengganu. Persatuan Sejarah Malaysia Cawangan Terengganu.

Mohamed Anwar Omar Din, Nik Anuar Nik Mahmud \& Jawatankuasa Teknikal \& Sidang Editor, Yayasan Diraja Sultan Mizan. (2011). Sejarah Kesultanan Terengganu 17082008 (New Edition). Terengganu: Yayasan Diraja Sultan Mizan.

Parker, Edward Harper. (1888). Chinese Account of the Opium War. Shanghai: Kelly \& Walsh Limited.

Raimy Che Ross. (2012). Diri sahabat kita iaitu nyata raja tiada di bahawa perintah siapasiapa: Mengekalkan kedaulatan Terengganu - perutusan Baginda Omar (1839-1876) ke Great Britain (1869). Abdul Rahman Embong (Ed.), Terengganu Merentasi Tiga Abad (pp. 102-129). Terengganu: Yayasan Diraja Sultan Mizan.

Raimy Che Ross. (2015). The Royal Letters of Baginda Omar. Terengganu: Yayasan Diraja Sultan Mizan.

Raja Ali Haji. (1984). Salasilah Melayu dan Bugis. Mohd Yusof Md. Nor (Ed.). Kuala 


\section{Lumpur: Fajar Bakti.}

Raja Ali Haji. (1998). Tuhfat al-Nafis. Hooker V. M. (Ed.). Kuala Lumpur: Yayasan Karyawan dan Dewan Bahasa dan Pustaka.

Sheppard, M. C. ff . (1949). A Short History of Trengganu. Journalof the Malayan Branch of the Royal Asiatic Society, 22(3), (149), 1-74.

Sivachanralingam Sundara Raja. (2000). Policy of Free Trade And Freeports in the Straits Settlements in the Late Eighteen than Dearly Nineteenth Century. SEJARAH: Jurnal Jabatan Sejarah Universiti Malaya, 119-140.

Skinner, C. (1966). Abdullah's Voyage to the East Coast, Seen Through Contemporary Eyes. Journal of the Malaysian Branch of the Royal Asiatic Society, 39(2), (210), 23-33.

SOAS MS 40320/11, f.67 - Warkah Sultan Mansur Shah I kepada Francis Light (3 Safar 1207)

SOAS MS 40320/11, f.68 - Warkah Sultan Mansur Shah I kepada Francis Light (6 Safar 1202)

SOAS MS 40320/11, f.69 - Warkah Sultan Mansur Shah I kepada Francis Light (15Syaaban1201)

SOAS MS 40320/11, f.71 - Warkah Sultan Mansur Shah I kepada Francis Light (14Zulkaedah1203)

SOAS MS 40320/11, f.74 - Warkah Sultan Mansur Shah I kepada Francis Light

SOAS MS 40320/11, f.75 - Warkah Sultan Mansur Shah I kepada Francis Light (7Muharam1203)

SOAS MS 40320/11, f.77 - Warkah Sultan Mansur Shah I kepada Francis Light (23Rabiul Akhir1204)

SOAS MS 40320/11,f.78 - Warkah Sultan Mansur Shah I kepada Francis Light (15Safar1200)

SOAS MS 40320/11, f.80 - Warkah Sultan Mansur Shah I kepada Francis Light (10Jamadil Akhir1206)

SOAS MS 40320/11, f.83 - Warkah Saudagar Nasruddin kepada Francis Light (26Muharam1206)

SOAS MS 40320/11, f.85 - Warkah Sultan Mansur Shah I kepada Francis Light (18 Zulkaedah 1201)

SOAS MS 40320/11, f.88 - Warkah Saudagar Nasruddinkepada Francis Light (19Muharam1204)

SOAS MS 40320/11, f.92 - Warkah Saudagar Nasruddin kepada Francis Light (16Syaaban1205)

SOAS MS 40320/11, f.97 - Warkah Sultan Mansur Shah I kepada Francis Light (12Jamadil Awal1206)

SOAS MS 40320/11, f.98 - Warkah Sultan Mansur Shah I kepada Francis Light (2Muharam1207)

SOAS MS 40320/11, f.100 - Warkah Sultan Mansur Shah I kepada Francis Light (12Rejab1207) 
SOAS MS 40320/11, f.102 - Warkah Sultan Zainal Abidin II kepada Francis Light (10Rejab1208)

SOAS MS 40320/11, f.108 - Draf surat Francis Light kepada Sultan Terengganu

Sweeney, Amin. (2005). Karya Lengkap Abdullah bin Abdul Kadir Munsyi (Jilid 1). Jakarta: Kepustakaan PopulerGramedia.

Trocki, Carl A. (2013). Prince of Pirates. Singapore: NUS Press.

Wurtzburg, C.E. (1938). A Brief Account of the Several Countries Surrounding Prince of Wales's Island With Their Production: Recd. From Captain Leight: Enclosed in Lord Cornwallis's Letter to Mr. Dundas, Dated 7th January, 1789. Journal of the Malayan Branch of the Royal Asiatic Society, 16(1), (130), 123-126.

Tarikh Peroleh (received): 09 September 2019

Tarikh Terima (accepted): 18 Jun 2020 